Економічні науки: збірник наукових праџь Луцького національного технічного університету. Серія "Регіональна економіка". Випуск 17 (67). Редкол.: відп. ред. к.е.н., професор І.В. Кривов’язюк. Луцьк: ІВВ Луцького НТУ, 2020. 348 с.

УДК 658:339

Таран С.Ф.,

головний спеціаліст відділу розвитку дослідницької

та інноваційної інфраструктури Головного управління

iз реалізації політик у сфері науки та інновацій

директорату науки та інновацій МОН України

\title{
ФОРМИ ІННОВАЦІЙНОГО ПІДПРИЄМСТВА РЕГІОНУ: ВЕКТОРИ НАЦІОНАЛЬНОГО ТА СВІТОВОГО ДОСВІДУ
}

У статті розглянуті теоретичні положення інноваційного розвитку підприємств із врахуванням світового досвіту. Визначено, що ефективне функціонування технополісів, міст високих технологій (HiTech City), технопарків, науково-технічних альянсів, інноваційних центрів, бізнесінкубаторів, спеціальних економічних зон, консалтингових фірм і компаній, а також консорціумів, концернів, кластерів, холдингів, фінансово-промислових груп та ін. допомагає вдосконалити галузеву структуру виробництва i прискорити соціально-економічний розвиток підприємств; активно впроваджувати у виробництво вітчизняні i зарубіжні науково-технічні розробки i винаходи 3 подальшою передачею результатів для широкого використання на внутрішньому та зовнішньому ринку.

Ключові слова: інноваційне підприємництво, інновації, інноваційна інфраструктура, технологічні парки.

\section{Taran S.}

\section{FORMS OF INNOVATIVE ENTERPRISE OF THE REGION: VECTORS OF NATIONAL AND WORLD EXPERIENCE}

The article considers the theoretical provisions of innovative development of enterprises, taking into account world experience. It is determined that the effective functioning of technopolises, high-tech cities (HiTech City), technology parks, science and technology alliances, innovation centers, business incubators, special economic zones, consulting firms and companies, as well as consortia, concerns, clusters, holdings, financial industrial groups, etc. helps to improve the sectoral structure of production and accelerate the socio-economic development of enterprises; actively implement in production domestic and foreign scientific and technical developments and inventions with the subsequent transfer of results for widespread use in the domestic and foreign markets.

Modern conditions of globalization lead to increased competition in the markets and force companies to seek new effective methods of work. In the struggle for the consumer, the key positions are occupied by the most competitive 
Економічні науки: збірник наукових праць Луиького національного технічного університету. Серія "Регіональна економіка". Випуск 17 (67). Редкол.: відп. ред. к.е.н., професор І.В. Кривов’язюк. Луцьк: ІВВ Луцького НТУ, 2020. 348 с.

enterprises, including those that can adapt to new conditions in the shortest possible time and are capable of constant innovation. Moreover, global innovations do not provide companies with long-term competitive advantage in the market, but give them only a temporary advantage. The requirement of time is constant monitoring of the market situation with the possibility of providing constant modifications of products / services and methods of work in the market. This encourages companies to find effective methods of tracking possible sources of innovation and ways to implement them. That is why the modern model of enterprise development should be based on the development of effective innovation models.

On the basis of the conducted assessment of factors of influence the enterprise can choose the following directions of innovative development. According to the strategic direction of innovative development, there are areas: balanced innovative development, which is applied subject to gradual technical changes; offensive innovative development, which is used in conditions of rapid technical change, when it is necessary to advance or maintain market leadership through the use of new achievements of STP; protective innovative development through the use and gradual reproduction of the results of innovative activities of market leaders; absorbing innovative development, through nominal, not real innovative transformations.

According to many experts, the main problems hindering innovation in Ukraine are: an imperfect system of legal support and state support. For a long time, the innovation legislation of Ukraine was characterized by a certain fragmentation and inconsistency. However, most of the mechanisms of state financial support and tax incentives provided by these acts cannot be fully applied. The lack of a systematic approach and a unified scientific and technological and innovation policy is not compensated by the increase in the number of legislative and regulatory acts, numerous changes and additions to them.

The application of effective models of economic growth is available in those countries whose public policy is based on an innovative model of development, which provides for the creation of state-of-the-art production based on fundamentally new advanced technologies and high-tech products, intellectualization of production, improvement of financial markets management, conducting a policy of resource conservation, creation and support of technology parks, technology cities and other innovation structures.

In any developed country, innovation is the basis of radical changes that must be carried out to ensure economic growth. At the present stage of development of globalization processes in the economy, the national security of the state, the competitiveness of its economy, as well as living standards determine, first of all, the development of scientific and technological progress and effective use of intellectual activity of leading scientists. The competition that exists among the countries of the world has turned into competition in the field of science, technology and education.

Key words: innovative entrepreneurship, innovations, innovative infrastructure, technology parks. 

університету. Серія "Регіональна економіка". Випуск 17 (67). Редкол.: відп. ред. к.е.н., професор І.В. Кривов’язюк. Луцьк: ІВВ Луцького НТУ, 2020. 348 с.

Таран С.Ф.

\section{ФОРМЫ ИННОВАЦИОННОГО ПРЕДПРИЯТИЯ РЕГИОНА: ВЕКТОР НАЦИОНАЛЬНОГО И МИРОВОГО ОПЫТА}

В статье рассмотрены теоретические положения инновационного развития предприятий с учетом мирового опыта. Определено, что эффективное функционирование технополисов, городов высоких технологий (HiTech City), технопарков, научно-технических альянсов, инновационных центров, бизнес-инкубаторов, специальных экономических зон, консалтинговых фирм и компаний, а также консорциумов, концернов, кластеров, холдингов, финансово промышленных групп и др. помогает усовершенствовать отраслевую структуру производства и ускорить социально-экономическое развитие предприятий; активно внедрять в производство отечественные и зарубежные научно-технические разработки и изобретения с последующей передачей результатов для широкого использования на внутреннем и внешнем рынке.

Ключевые слова: инновационное предпринимательство, инновации, инновационная инфраструктура, технологические парки.

Постановка проблеми у загальному вигляді та їі зв'язок 3 важливими науковими та практичними завданнями. Інноваційний розвиток підприємств - завжди відіграє провідну роль у сучасній економіці багатьох країн світу. Враховуючи всі економічні, політичні, соціальні зміни у нашій країні, інноваційна складова розвитку підприємств та використання сучасних наукових технологій дозволяє країнам 3 розвиненою економікою завжди залишатися світовими лідерами та займати провідні місця серед країн з розвиненим ВВП.

Сучасні умови глобалізації призводять до посилення конкуренції на ринках і змушують підприємства до пошуку нових ефективних методів роботи. У боротьбі за споживача ключові позиції займають найбільш конкурентоспроможні підприємства, серед яких ті, які можуть у максимально короткий термін адаптуватись до нових умов i здатні до постійних упроваджень інновацій. Причому глобальні інновації не забезпечують підприємствам тривалого утримання конкурентних переваг на ринку, а дають їм лише тимчасову перевагу. Вимогою часу $є$ постійний моніторинг ринкової 
Економічні науки: збірник наукових праць Луиького національного технічного університету. Серія "Регіональна економіка". Випуск 17 (67). Редкол.: відп. ред. к.е.н., професор І.В. Кривов'язюк. Луиьк: ІВВ Луцького НТУ, 2020. 348 с.

ситуації з можливістю забезпечення постійних модифікацій продуктів/послуг та методів роботи на ринку. Це стимулює підприємства до пошуку ефективних методів відслідковування можливих джерел інновацій та шляхів їх упровадження. Саме тому сучасна модель розвитку підприємства має будуватись на засадах розробки ефективних інноваційних моделей.

Про недостатній рівень інноваційної активності підприємств свідчать показники обсягів реалізованої інноваційної продукції в Україні. У загальному обсязі промислової продукції лише 3,8 \% мають ознаки інновацій (в Євросоюзі - 75 \%). Крім цього, спостерігається безупинне зниження рівня наукомісткості вітчизняної продукції. Інноваційна система України переживає не найкращі часи свого розвитку, що пов'язано насамперед 3 складними соціальноекономічними чинниками: світова економічна криза, пандемія COVID-2019, закриття багатьох великих підприємств, скорочення штатів працівників та ін.

За оцінками, наданими провідними науковцями, технологічні інновації забезпечують до 80\% приросту валового внутрішнього продукту. I, перш за все, невід'ємною складовою економічного зростання світових країн-лідерів $\epsilon$ розвиток науково-інноваційних процесів. Інноваційна спроможність та технологічна готовність багатьох країн світу забезпечує конкурентоспроможність економіки та постійний їі розвиток.

На думку багатьох експертів основними проблемами, які стримують інноваційну діяльність в Україні є: недосконала система нормативно-правового забезпечення та державної підтримки. Тривалий період інноваційному законодавству України була властива певна фрагментарність та непослідовність. Разом $з$ тим, більшість механізмів державної фінансової підтримки та податкового стимулювання, передбаченого цими актами, не можуть бути застосовані в повному обсязі. Відсутність системного підходу та єдиної науково-технологічної та інноваційної політики не компенсується збільшенням кількості i законодавчих i 
Економічні науки: збірник наукових праць Луиького національного технічного університету. Серія "Регіональна економіка". Випуск 17 (67). Редкол.: відп. ред. к.е.н., професор І.В. Кривов'язюк. Луиьк: ІВВ Луцького НТУ, 2020. 348 с.

нормативно-правових актів, численними змінами та доповненнями до них [1-5, 7-10].

Застосування ефективних моделей економічного зростання $є$ наявним у тих країнах, державна політика яких базується на інноваційній моделі розвитку, яка передбачає створення надсучасних виробництв на основі використання принципово нових прогресивних технологій та випуску високотехнологічної продукції, інтелектуалізацію виробничої діяльності, удосконалення системи управління фінансовими ринками, оптимізацію системи освіти, проведення політики ресурсозбереження, створення та підтримки технопарків, технополісів та інших інноваційних структур.

В будь-якій розвиненій країні інновації - це основа радикальних перетворень, які повинні здійснюватися на шляху забезпечення економічного зростання. На сучасному етапі розвитку глобалізаційних процесів у економіці національну безпеку держави, конкурентоспроможність іiі економіки, а також рівень життя людей визначають, в першу чергу, розвиток науково-технічного прогресу та ефективне застосування результатів інтелектуальної діяльності провідних науковців країни. Конкуренція, яка існує серед країн світу, перетворилася на конкуренцію у сфері науки, технологій та освіти.

Аналіз останніх досліджень, у яких започатковано вирішення проблеми. Теоретико-методологічну базу сучасних наукових досліджень присвячених вивченню впливу інноваційної діяльності на розвиток економіки України вивчали: В. Бакуменко, В. Бодров, В. Геєць, В. Гусєв, Т. Гончарова, Н. Гнидюк, І. Грицяк, В. Дзюндзюк, Ю. Кальниш, О. Кілієвич, І. Коліушко, В. Копійка, Е. Лібанова, В. Князєв, Л. Ковальська, В. Корженко, О. Лебединська, В. Луговий, О. Малиновська, В. Муравйов, П. Надолішний, Н. Нижник, С. Озірська, В. Опришко, О. Оржель, Р. Петров, І. Розпутенко, О. Романюк, С. Серьогін, Г. Ситник, В. Семиноженко, Г. Ситник, І. Солоненко, Ю. Сурмін, Т. I. Тищенко, В. Трощинський, А. Філіпенко, О. Чалий та ін., а також зарубіжних науковців, які вивчали інноваційну діяльність країн 
Економічні науки: збірник наукових праць Луиького національного технічного університету. Серія "Регіональна економіка". Випуск 17 (67). Редкол.: відп. ред. к.е.н., професор І.В. Кривов'язюк. Луиьк: ІВВ Луцького НТУ, 2020. 348 с.

світу: P. Aghion, A. Arundel, C. Bordoy, M. Henrekson, D. Johansson , M. Kanerva, J. Kozlowski, B. Majcen, S. Radosevis, M. Rojec та ін.

Інтеграція української науки в світовий дослідницький простір повинна реалізовуватися за різними формами наукового співробітництва (програмами, договорами, замовленнями на науково-технічну продукцію).

Мета статті - теоретично обгрунтувати особливості інноваційного підприємництва регіону з урахуванням світового досвіду.

\section{Виклад основного матеріалу дослідження 3 повним} обгрунтуванням отриманих наукових результатів. Стримування інноваційної діяльності промислових підприємств України пояснюється, насамперед, обмеженістю джерел іiі фінансування, що пов'язано 3 фінансово-економічною нестабільністю в державі та кризовим станом більшості підприємств, які змушені реалізовувати інноваційні процеси за рахунок власних коштів. Відсутність власних коштів у підприємств для фінансування інновацій доповнюється іншими чинниками - високими кредитними ставками та неспроможністю отримання довготермінових кредитів, теперішнім масовим банкрутством банків. Недостатньо використовуються в Україні непрямі заходи стимулювання впровадження інновацій.

У світовій практиці на сьогодні сформувалися три головні типи моделей науково-інноваційного розвитку промислово розвинутих країн:

- країни, орієнтовані на лідерство в науці, реалізацію великомасштабних цільових проектів, що охоплюють усі стадії науково-виробничого циклу, як правило, зі значною часткою науково-інформаційного потенціалу в оборонному секторі (США, Англія, Франція);

- країни, орієнтовані на поширення нововведень, створення сприятливого інноваційного середовища, раціоналізацію всієї структури економіки (Німеччина, Швеція, Швейцарія); 
Економічні науки: збірник наукових праць Луиького національного технічного університету. Серія "Регіональна економіка". Випуск 17 (67). Редкол.: відп. ред. к.е.н., професор І.В. Кривов'язюк. Луиьк: ІВВ Луцького НТУ, 2020. 348 с.

- країни, де стимулюються нововведення шляхом розвитку інноваційної інфраструктури, сприйнятливості щодо досягнень світового науково-технічного прогресу, координації дій різноманітних секторів у галузі науки і технологій (Японія, Південна Корея).

Інноваційним підприємством вважається підприємство (об'єднання підприємств) будь-якої форми власності, якщо більше ніж 70 \% обсягу його продукції складає інноваційна продукція (продукти) [5, с. 34-39].

Інноваційною визнається продукція, яка $\epsilon$ результатом виконання інноваційного проекту або виробляється вперше, є конкурентоздатною і має вищі техніко-економічні показники.

Інноваційне підприємство може функціонувати у вигляді інноваційного центру, бізнес-інкубатора, технополісу, технопарку тощо.

Зараз в Україні визначилися декілька організаційних форм реалізації інноваційної діяльності:

- університетські науково-дослідні центри, де відбувається ефективне об'єднання фінансових ресурсів, кваліфікованих наукових кадрів, матеріально-технічної бази;

- технопарки - акціонерні товариства, які займаються патентуванням, рекламою, маркетингом, консалтингом, лізингом, орендою в сфері науково-технічної діяльності;

- технополіси - якісно нова територіальна форма інтеграції науки і виробництва, що забезпечує високі темпи науково-технічного розвитку за рахунок можливостей регіону;

- бізнес-інкубатори - дрібні наукомісткі фірми, на яких створені сприятливі умови для створення сучасних наукових продуктів, навчання кадрів, стимулювання власного бізнесу;

- венчурні підприємства - малі підприємства, які забезпечують зв'язок між фундаментальними дослідженнями i масовим виробництвом, спеціалізуються на розробці нових наукових ідей та їх втіленні у виробництво.

Напрямок інноваційного розвитку підприємства - це окреслення шляху або руху до впровадження i реалізації інновацій, які забезпечують покращення кількісних та якісних 
Економічні науки: збірник наукових праць Луиького національного технічного університету. Серія "Регіональна економіка". Випуск 17 (67). Редкол.: відп. ред. к.е.н., професор І.В. Кривов'язюк. Луиьк: ІВВ Луцького НТУ, 2020. 348 с.

характеристик діяльності підприємства, зміцнення його ринкових позицій та створюють умови для висхідного розвитку. Для того, щоб обрати певний напрямок інноваційного розвитку, менеджерам підприємства необхідно визначити та оцінити силу впливу факторів успіху інноваційного розвитку (табл. 1) $[4,5,8]$.

Як слушно зазначає П.П. Микитюк [5, с. 47-39] на основі проведеної оцінки факторів впливу підприємство може обрати наступні напрями інноваційного розвитку. Відповідно до стратегічної спрямованості інноваційного розвитку існують напрямки:

- збалансованого інноваційного розвитку, який застосовують при умові поступових технічних змін;

- наступального інноваційного розвитку, який використовують в умовах швидких технічних змін, коли необхідно досягти випередження або збереження лідерства на ринку через використання нових здобутків НТП;

- захищаючого інноваційного розвитку шляхом використання та поступового відтворення результатів інноваційної діяльності підприємств-лідерів ринку;

- абсорбуючого інноваційного розвитку, через номінальні, а не реальні інноваційні перетворення.

Так, основні фактори впливу на інноваційний розвиток підприємства регіонів наведені в таблиці 1 .

За масштабами та рівнями охоплення напрямки інноваційного розвитку класифікуються на: локальні, що спрямовані на внутрішні зміни на підприємстві; глобальні, які покликані змінити не тільки внутрішню структуру, а й призводять до певних змін у зовнішньому середовищі функціонування підприємств; стратегічні, що спрямовані на реалізацію окреслених інноваційних ідей; тактичні, які проявляються в поточній діяльності підприємства і реалізують досягнення оперативних цілей щодо інноваційної діяльності. 
Економічні науки: збірник наукових праць Луиького начіонального технічного університету. Серія "Регіональна економіка". Випуск 17 (67). Редкол.: відп. ред. к.е.н., професор І.В. Кривов’язюк. Луцьк: ІВВ Луцького НТУ, 2020. 348 с.

Таблиця 1

Основні фактори впливу на інноваційний розвиток підприємства регіонів

\begin{tabular}{|c|c|}
\hline п.н. & $\begin{array}{c}\text { Характеристика факторів успіху інноваційного розвитку } \\
\text { підприємства регіонів }\end{array}$ \\
\hline 1 & $\begin{array}{l}\text { узгодження цілей інноваційного розвитку підприємства і цілей } \\
\text { розвитку зовнішнього середовища; }\end{array}$ \\
\hline 2 & $\begin{array}{l}\text { узгодження ресурсних потреб та інноваційних можливостей } \\
\text { підприємства. }\end{array}$ \\
\hline 3 & $\begin{array}{l}\text { узгодження стратегії і тактики розподілу ресурсів у продовж } \\
\text { конкретної фази життєвого циклу підприємства. }\end{array}$ \\
\hline 4 & $\begin{array}{l}\text { узгодження всіх видів господарсько-технологічних процесів } \\
\text { підприємства в єдиному алгоритмі }\end{array}$ \\
\hline 5 & $\begin{array}{llll}\text { узгодження } \\
\text { підприємства. }\end{array}$ \\
\hline 6 & узгодження всіх комунікацій між підрозділами підприємства \\
\hline 7 & $\begin{array}{l}\text { узгодження дій оперативного регулювання і координації } \\
\text { діяльності підрозділів }\end{array}$ \\
\hline 8 & $\begin{array}{l}\text { узгодження кадрової політики підрозділів, системи навчання та } \\
\text { перепідготовки персоналу }\end{array}$ \\
\hline 9 & $\begin{array}{l}\text { узгодження цілей і завдань підприємства та інтересів персоналу } \\
\text { у системі мотивації }\end{array}$ \\
\hline 10 & $\begin{array}{l}\text { узгодження факторів системи якості підприємства і рівня } \\
\text { задоволення потреб споживачів }\end{array}$ \\
\hline 11 & $\begin{array}{lcccc}\text { узгодження } & \text { маркетингової політики } \\
\text { аналітико-дослідницького потенціалу } & & & & \\
\end{array}$ \\
\hline 12 & $\begin{array}{l}\text { узгодження фінансових перспектив та ресурсних можливостей } \\
\text { підприємства. }\end{array}$ \\
\hline
\end{tabular}

Кожна національна інноваційна система країн-світових лідерів 3 розвиненою економікою характеризується певною структурою та ступенем упорядкованості, що передбачає достатню стабільність інституційної взаємодії (рис 1 ). Серед основних підсистем інноваційної системи є наступні:

- генерація знань;

- освіта і професійна підготовка;

- виробництво продукції та послуг;

- інноваційна інфраструктура, включаючи інфраструктуру фінансового та інформаційного забезпечення. 
Економічні науки: збірник наукових праиь Луиького національного технічного університету. Серія "Регіональна економіка". Випуск 17 (67). Редкол.: відп. ред. к.е.н., професор І.В. Кривов’язюк. Луцьк: ІВВ Луцького НТУ, 2020. 348 с.

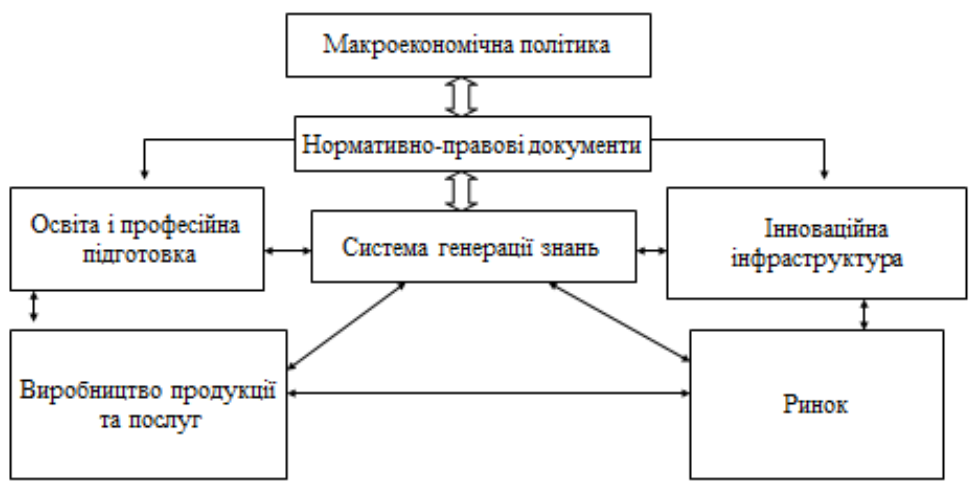

Рис. 1 Основні підсистеми інноваційної системи та взаємодії між ними у країнах з розвинутою економікою [4].

Де підсистемою генерації знань є сукупність організацій, що виконують фундаментальні дослідження і розробки, а також прикладні дослідження.

Підсистема виробництва продукиії та послуг включає виробництво наукомісткої продукції, що здійснюється як великими корпораціями, так i малими та середніми підприємствами, які працюють в сфері наукомісткого бізнесу.

Підсистема інновачійної інфраструктури вміщує такі елементи як: бізнес-інноваційні, телекомунікаційні та торгові мережі, технологічні парки, бізнес-інкубатори, інноваційнотехнологічні центри, консалтингові фірми, фінансові структури та інше [9, с. 5-7].

Інституційні зміни повинні торкнутися ключових елементів, зокрема продукування наукових знань та інновацій, ïх комерціалізації та використання, інформаційного забезпечення інноваційного розвитку, державного управління цим розвитком на різних рівнях, освіти, перепідготовки i підвищення кваліфікації кадрів, формування інноваційної культури суспільства [7, с. 69-76]. 
Економічні науки: збірник наукових праць Луиького національного технічного університету. Серія "Регіональна економіка". Випуск 17 (67). Редкол.: відп. ред. к.е.н., професор І.В. Кривов'язюк. Луиьк: ІВВ Луцького НТУ, 2020. 348 с.

Також інституційні трансформації в інноваційній сфері повинні також включати права інтелектуальної власності, фінансово-кредитне забезпечення (зокрема, інститут спеціальних фондів), наукову та інноваційну інфраструктуру, систему наукових, науково-технічних та інноваційних програм різного рівня, статистичну звітність [7, с. 69-76].

До основних принцииів інституційних трансформацій $в$ інноваційній сфері науковці відносять:

-системність інституційних процесів: необхідність врахування взаємодії та супідрядності різних рівнів господарського механізму та інноваційної сфери, в межах яких проходять інституційні трансформації;

-узгодженість інституційних процесів в інноваційній сфері із загальними соціально-економічними інституційними трансформаціями: забезпечення повноти врахування витрат та ефектів (включаючи оцінку екологічних, соціальних та інших факторів), однорідності та достовірності всіх складових;

-комплексність оцінки інституційних процесів: врахування всебічних наслідків інституційних процесів як в межах інноваційної сфери діяльності, так і поза їі межами;

-варіативність шляхів розвитку інституціонального середовища: розробка можливих сценаріїв інституціональних трансформацій в інноваційній сфері залежно від загальнонаціональних цілей розвитку суспільства та внутрішніх закономірностей i можливостей інноваційного розвитку економіки;

-динамічність процесів інституційних змін в інноваційній сфері: систематичне поповнення і уточнення напрямів інституційних процесів в інноваційній сфері в середньо і довгостроковій перспективі по мірі надходження інформації щодо пріоритетності соціально-економічного розвитку країни, інтенсивності використання ресурсів та особливостей впливу світових інтеграційних процесів;

-адаптивність інституційних процесів: гнучкість i своєчасне коригування напрямків та структури інноваційних 
Економічні науки: збірник наукових праць Луиького національного технічного університету. Серія "Регіональна економіка". Випуск 17 (67). Редкол.: відп. ред. к.е.н., професор І.В. Кривов’язюк. Луцьк: ІВВ Луцького НТУ, 2020. 348 с.

змін в інноваційній сфері залежно від проявів непередбачуваних змін;

керованість інституційними

процесами: цілеспрямованість інституційних трансформацій на основі реалізації державної інноваційно-промислової політики, запровадження відповідних фінансово-економічних механізмів щодо управління інноваційним розвитком економіки $[3,4,5,6]$.

Залучення України до співпраці з світовим досліднищьким простором вирішує комплекс завдань:

1) стабілізація наукового потенціалу цих держав;

2) сприяння розв'язанню проблем, пов'язаних зі спільним інтересом у галузі енергетики, поліпшення охорони здоров'я й забезпечення екологічної безпеки, включаючи ядерну;

3) зміцнення кадрових ресурсів i поповнення їх молодими вченими та ін.

Зокрема, якщо проаналізувати основні реформи інноваційної політики у сфері науки, освіти, промисловості у країнах, які є лідерами розвитку інноваційної сфери, можна виділити основні чинники, які сприяли запровадженню державних реформ:

- розвиток академічної бази та дослідницьких програм;

- посилення наукового кадрового потенціалу;

- відкриття ряду установ підвищення кваліфікації науковців, зокрема у сфері сучасних прикладних технологій;

- комерціалізація функцій освітніх установ третього та четвертого рівня акредитації: економізація наукової діяльності, ноу-хау, патентів, продуктів інтелектуальної власності з метою практичного застосування спеціалізованих досліджень;

- розвиток промислових досліджень у співпраці з ВНЗ. Збільшення рівня щорічних витрат бізнесу на дослідження та запровадження нових технологій

Заснування ряду промислових дослідницьких центрів на базі ВНЗ;

- здійснення секторальних досліджень 3 метою економічного та соціального прогресу. Застосування 
Економічні науки: збірник наукових праць Луиького національного технічного університету. Серія "Регіональна економіка". Випуск 17 (67). Редкол.: відп. ред. к.е.н., професор І.В. Кривов'язюк. Луиьк: ІВВ Луцького НТУ, 2020. 348 с.

результатів дослідницької діяльності шляхом реалізації відповідної державної політики. Надання на конкурсній основі грантів з метою стимулювання досліджень у сфері соціальних, економічних, екологічних потреб та охорони довкілля;

- проведення інформаційної роботи з метою посилення громадської свідомості у сфері інноваційних технологій. Збільшення кількості студентів, що спеціалізуватимуться на вивченні точних наук;

- посилення транскордонного співробітництва $[3,4,5,6]$.

-Поєднання їх 3 практичними розробками створює базис інновацій - науково-дослідні та дослідницько-конструкторські розробки (НДДКР).

Відповідно до основних видів інновачійної діяльності відносять:

- здійснення внутрішніх науково-дослідних розробок творча діяльність на систематичній основі, яка виконується власними силами 3 метою збільшення обсягу знань для розробки нових i вдосконалених продуктів та процесів (включно 3 розробкою програмного забезпечення власними силами підприємства, що відповідає цій меті);

- придбання зовнішніх науково-дослідних розробок придбання науково-дослідних розробок, виконаних іншими підприємствами (включно з іншими підприємствами групи), державними або приватними науково-дослідними організаціями та придбані підприємством;

- придбання машин, обладнання та програмного забезпечення - придбання передового машинного обладнання й комп'ютерного машинного та програмного забезпечення для впровадження нових або суттєво вдосконалених продуктів i процесів;

- придбання зовнішніх знань - купівля або ліцензування патентів та незапатентованих винаходів, ноу-хау, а також інших видів знань в інших підприємствах чи організаціях для розробки та впровадження нових або суттєво вдосконалених продуктів і процесів; 
Економічні науки: збірник наукових праць Луиького національного технічного університету. Серія "Регіональна економіка". Випуск 17 (67). Редкол.: відп. ред. к.е.н., професор І.В. Кривов'язюк. Луиьк: ІВВ Луцького НТУ, 2020. 348 с.

- навчальна підготовка для інновачійної діяльності внутрішнє або зовнішнє навчання персоналу саме для розробки та / або впровадження нових чи суттєво вдосконалених продуктів і процесів;

- ринкове впровадження інноващій - діяльність щодо ринкового впровадження нових або суттєво вдосконалених товарів і послуг, включно 3 маркетинговими дослідженнями та рекламною кампанією;

- інші види інноваційної діяльності - інші види діяльності для впровадження нових або суттєво вдосконалених продуктів та процесів таких як техніко-економічні обгрунтування, тестування, розробка програмного забезпечення для поточних потреб, технічне оснащення, організація виробництва тощо [6].

Інновачійною продукиією - $є$ впроваджена на ринку продукція (товари, роботи або послуги), що є новою або значно вдосконаленою в частині піi властивостей або способів використання. Продукція (нова або удосконалена) може бути новою для певного підприємства, а не лише новою для певного сектору діяльності або ринку загалом $[3,4,5,6]$.

До обсягу інноваційної продукиї відноситься вищезазначена продукція, що впроваджувалась у виробництво протягом звітного періоду та була реалізована на вітчизняному ринку.

Також серед основних термінів у науковій літературі хотілося б виділити термін «технологічних інноващіï».

Технологічні інновації - це розробка та впровадження як технологічно нових, так і значно технологічно вдосконалених продуктів (продуктові інноваціі) і процесів (процесові інновації) [3-9].

Державна політика у науковій та науково-технічній сфері реалізується за допомогою різних інструментів. Підтримка в державному секторі включає підтримку як фундаментальних досліджень, так i прикладних досліджень із потенційним комерційним застосуванням. Сюди входять законодавство, податкова політика, розмір і характер розподілу бюджетних засобів, у тому числі на проведення робіт із пріоритетних 
Економічні науки: збірник наукових праць Луиького національного технічного університету. Серія "Регіональна економіка". Випуск 17 (67). Редкол.: відп. ред. к.е.н., професор І.В. Кривов'язюк. Луиьк: ІВВ Луцького НТУ, 2020. 348 с.

напрямків, формування і підтримка інфраструктури, кадрове забезпечення [3-9].

В науковій літературі виокремлюють наступні методи державного регулювання інновачійних процесів, із них до прямих методів належать:

- Державні иільові програми забезпечують фінансування інновацій у пріоритетних галузях економіки, що визначає держава;

- Адміністративне регулювання передбачає пряме дотаційне фінансування, що надається відповідно до чинного законодавства;

- Контрактне фінансування - система договорів між замовниками та підрядниками, де держава виступає замовником та споживачем науково-дослідних розробок, а виконавцями суб'єкти господарювання. В договорі мають бути визначені чіткі терміни виконання робіт, розподіл завдань та матеріальної винагороди між виконавцями, а також взаємні зобов'язання й економічні санкції.

Непрямі методи направлені на стимулювання інноваційних процесів та створення сприятливого середовища для інноваційної діяльності, це, насамперед, законодавчі норми, що окреслюють правове поле діяльності інноваційних фірм та захист їх інтелектуальної власності, ma інформаційна інфраструктура, що забезпечує формування єдиної інформаційної системи в країні [7].

Також серед основних непрямих методів державного регулювання у багатьох країнах світу є: спрощена система оподаткування; амортизаційні відрахування, грошово-кредитне регулювання та ін.

У Німеччині компаніям надаються субсидії, що не оподатковуються податком на дослідні роботи, у розмірі від 7 до $15 \%$ суми на НДДКР, якщо проект пов'язаний $з$ пошуком нових джерел енергії. Система податкових і амортизаційних пільг у всіх країнах будується таким чином, щоб, по-перше, забезпечити ї цілеспрямований характер i конкретну 
Економічні науки: збірник наукових праць Луиького національного технічного університету. Серія "Регіональна економіка". Випуск 17 (67). Редкол.: відп. ред. к.е.н., професор І.В. Кривов'язюк. Луиьк: ІВВ Луцького НТУ, 2020. 348 с.

регламентацію діяльності власних корпорацій, спрямованої на технологічний розвиток виробництва.

У всіх промислово розвинених країнах використовують податкові пільги для стимулювання малого наукомісткого бізнесу. 3 цією метою здійснюється оподаткування прибутку невеликих фірм за зниженими ставками [8-10].

Наприклад, у Великій Британії податкова ставка на прибуток дрібних і середніх фірм становить $29 \%$ (стандартна ставка - $35 \%$ ). Податкові знижки сприяли виникненню одного 3 різновидів спеціалізованих ризикових підприємств - так званих «обмежених науково-дослідних партнерств». Грошові інвестиції заможних осіб і корпорацій у ці партнерства списуються як поточні витрати і на 80-90 \% виключаються з оподатковуваного доходу. Партнерства створюються для фінансування розробки i прискорення комерціалізації вже створених винаходів. Найінтенсивніше вони виникають в електроніці, виробництві засобів зв'язку $[14,15]$.

Іншим методом непрямого стимулювання НДДКР, а отже, i технічного переозброєння підприємств $€$ амортизаційна політика. Так амортизаційні відрахування є специфічним видом фінансових ресурсів. 3 одного боку, амортизаційні відрахування - це витрати підприємства, тому що їхню суму, нараховану на виробничі необоротні активи, включають у собівартість продукції, робіт, послуг.

Більшість промислово розвинених країн здійснює політику прискореної амортизації основного капіталу i передбачає особливі пільги в цій сфері. Наприклад, у Франції, Італії, Німеччині дозволяється списувати устаткування та нерухомі елементи основного капіталу протягом першого року експлуатації в розмірі 50 \% вартості їхнього придбання $[14,15]$.

Прискорена амортизація застосовується 3 метою збільшення швидкості його оборотності відповідно до вимог інноваційного відновлення.

Також до непрямих методів реалізації інноваційної політики належать урядові закупівлі розробок інноваційних проектів. Вони широко використовуються як засіб впливу на 
Економічні науки: збірник наукових праць Луиького національного технічного університету. Серія "Регіональна економіка". Випуск 17 (67). Редкол.: відп. ред. к.е.н., професор І.В. Кривов'язюк. Луиьк: ІВВ Луцького НТУ, 2020. 348 с.

НДДКР і впровадження у виробництво у Франції і Німеччині. Так, у Франції набули поширення конкурси на кращий проект громадських будівель, що сприяло вдосконаленням у галузі будівництва [12].

У багатьох країнах світу для реалізації стратегії інноваційного розвитку економіки, а також ефективної взаємодії влади, наукових установ, бізнесу використовуються такі основні інструменти:

Перший - державний контракт, який застосовується, якщо придбання державою результатів НДР приносить йому безпосередню вигоду або користь. При цьому не виключається можливість передачі придбаного продукту третій стороні. Підписання контракту за винятком спеціально обумовлених ситуацій є підсумком конкурсу. В процесі робіт за контрактом представник держави має право контролювати хід виконання роботи, коректувати їх.

Другий, найпоширеніший інструмент, - грант. Він легалізував іншу форму відносин між державою і науководослідним сектором, а саме підтримку або стимулювання державою наукових досліджень, розробок - фінансами, власністю, послугами. Причому передбачається, що до закінчення робіт за грантом держава не має права контролювати і втручатися в процес їх виконання, термін якого обмовляється спеціальною угодою. Грант часто застосовується для підтримки досліджень і розробок з боку держави, якщо результати робіт носять невизначений характер або не можуть принести безпосередню користь (вигоду) в найближчому майбутньому.

Кооперативна угода служить важливим інструментом організації кооперативних процесів між приватним і державним секторами, визначення форм сумісного інвестування і розподілу отриманого результату [4, с. 96-106].

До основних складових інноващійної інфраструктури належать: регіони науки, технополіси (зони науково-технічного розвитку), міста високих технологій (HiTech City), технопарки (дослідницькі, технологічні, промислові, аграрні), науковотехнічні альянси, інноваційні центри (технологічні, регіональні 
Економічні науки: збірник наукових праиь Луиького національного технічного університету. Серія "Регіональна економіка". Випуск 17 (67). Редкол.: відп. ред. к.е.н., професор І.В. Кривов'язюк. Луиьк: ІВВ Луцького НТУ, 2020. 348 с.

та галузеві), бізнес-інкубатори (інноваційні та технологічні), спеціальні економічні зони, консалтингові фірми і компанії та iн.

Також при реалізації наукомістких та інноваційних ідей особлива роль належить об’єднанням підприємницьких організацій, серед яких - консорціуми, концерни, кластери, холдинги, фінансово-промислові групи та інші організації $[14,15]$.

Як нами уже зазначалося, серед переліку основних складових інноваційної інфраструктури $є$ також бізнесінкубатори. Основною метою створення та функціонування бізнес-інкубаторів є об'єднання навчально-освітніх закладів, науково-дослідних установ та бізнесу щодо впровадження інноваційних форм підтримки підприємництва, використання сучасних інтерактивних методів бізнес-навчання та практичної підготовки переважно студентів економічних спеціальностей у сфері бізнесу.

Бізнес-інкубатори є інституціями для формування сприятливих умов для розвитку підприємництва та конкурентного середовища в регіоні; покращення доступу суб'єктів малого й середнього підприємництва до комплексу якісних бізнес-послуг, кластеризація консалтингу в регіоні; створення нових робочих місць, збільшення надходжень до бюджетів різних рівнів від діяльності суб' єктів підприємницької діяльності; зниження соціальної напруги в суспільстві, залучення населення до ведення бізнесу, формування позитивного іміджу «підприємця»; налагодження співпраці бізнесу з іноземними партнерами [4, с. 20-21].

Важливе значення для розвитку інноваційної політики кожної окремої країни у світі відіграють науково-технологічні та технологічні парки. У закордонній теорії та практиці поняття «науково-технологічний парк» використовується як узагальнююче поняття потужної інноваційної структури. До цієї групи також відносять дослідницькі центри та парки, наукові парки, центри провідних технологій, технологічні центри та 
Економічні науки: збірник наукових праць Луиького національного технічного університету. Серія "Регіональна економіка". Випуск 17 (67). Редкол.: відп. ред. к.е.н., професор І.В. Кривов'язюк. Луиьк: ІВВ Луцького НТУ, 2020. 348 с.

парки. Всі вони $є$ основою спеціалізованих інноваційних об'єднань, що створюються у провідних країнах світу.

Так, науково-технологічний парк - це технологічний центр, організований на спеціально відведених і підготовлених територіях, на яких знаходяться пов'язані центральними пунктами технологічного обслуговування науково-дослідні інститути, лабораторії, експериментальні центри та невелика кількість підприємств 3 передовою технологією, що виконують замовлення, пов'язані із створенням i освоєнням нових розробок [5-7].

А технологічним (науковим) парком - $€$ наукововиробничий комплекс (частіше територіальний), який включає в себе дослідний центр та найближчу компактну виробничу зону, в якій на умовах оренди розміщені малі наукомісткі фірми [2, с. 23-24].

Серед основних особливостей технопарків науковці виділяють наступні:

-найчастіше ця організація засновується на праві приватної власності;

- підтримує офіційні та робочі зв'язки з університетом, чи іншим навчальним закладом або провідним науково-дослідним центром;

-створюється для сприяння формування та розвитку наукомістких фірм та інших організацій, що є розміщеними на певній території;

- активно управляє передачею технологій та знань [4].

Технопарки виконують функції структури, що поєднує наукові дослідження, інноваційну діяльність та нововведення у науково-технічній сфері.

Найчастіше нові відкриття та привабливі ідеї комерційного використання нових наукових розробок i спеціалізовані фірми для їхньої реалізації зазвичай створюються на базі великих дослідницьких установ i університетів за особистої участі провідних вчених.

Одним із важливих завдань технологічних парків у всіх країнах світу $\epsilon$ комерціалізація результатів наукових 
Економічні науки: збірник наукових праць Луиького національного технічного університету. Серія "Регіональна економіка". Випуск 17 (67). Редкол.: відп. ред. к.е.н., професор І.В. Кривов'язюк. Луиьк: ІВВ Луцького НТУ, 2020. 348 с.

досліджень, винаходів та відкриттів вчених та спеціалістів, які займаються малим бізнесом у науково-технічній сфері, але потребують відповідної підтримки та здійснення технологічного трансферу [6] Також слід відзначити, що технопарки є надзвичайно ефективним механізмом формування, управління та реалізації інноваційних проектів у науковотехнологічній сфері [4, с. 186-187].

Отже, на основі позитивного досвіду розвитку інноваційного підприємництва у країнах 3 розвиненою економікою, можна зробити наступні висновки, що ефективне функціонування технополісів, міст високих технологій (НiТесh City), технопарків, науково-технічних альянсів, інноваційних центрів, бізнес-інкубаторів, спеціальних економічних зон, консалтингових фірм i компаній, а також консорціумів, концернів, кластерів, холдингів, фінансово-промислових груп та iн. допомагає вдосконалити галузеву структуру виробництва i прискорити соціально-економічний розвиток території; активно впроваджувати у виробництво вітчизняні і зарубіжні науковотехнічні розробки i винаходи 3 подальшою передачею результатів для широкого використання на внутрішньому та зовнішньому ринку.

Звичайно, що для ефективної реалізації поставленої мети необхідним є створення механізмів реальної взаємодії владних структур 3 науковим співтовариством, а також посилення реального впливу наукової громадськості на формування i реалізацію державної науково-технологічної та інноваційної політики. Значне місце у цьому процесі повинні відігравати нові підходи до формування інноваційної стратегії на основі використання кращих зразків світового досвіду у цій сфері.

\section{Список бібліографічного опису}

1. Економіка і суспільство: непізнані грані взаємовпливу (роздуми над прочитаним) / В. Геєць, А. Гриценко // Економіка України . 2015. № 3. С. 4-24.; Рейтинг інноваційності країн ЄC - Innovation Union Scoreboard 2013 [Електронний pecypc]. Режим доступу: http://ec.europa.eu/enterprise/policies/innovation/files/ius-2013_en.pdf.].

2. Інноваційний менеджмент: теорія i практика в умовах трансформації економіки / В.І. Захарченко, Н.М. Корсікова, М.М. Меркулов. Навч. посіб. - К. : Центр учбової літератури, 2016. 448 с. 
Економічні науки: збірник наукових праць Луиького національного технічного університету. Серія "Регіональна економіка". Випуск 17 (67). Редкол.: відп. ред. к.е.н., професор І.В. Кривов’язюк. Луцьк: ІВВ Луцького НТУ, 2020. 348 с.

3. Збірник наукових праць Міжнародної науково-практичної конференції «Науковий парк та інноваційна інфраструктура університету як основа розвитку освіти та науки». Луцьк : Східноєвроп. нац. ун-т ім. Лесі Українки, 2017. 216 с.

4. Інноваційна Україна 2020 : національна доповідь / за заг. ред. В.М. Гейця та ін. ; НАН України. К., 2015. 336 с. : табл., рис.

5. Інноваційний розвиток підприємства / За ред. П.П. Микитюка. Тернопіль: ПП «Принтер Інформ», 2015. 224 с.

6. Система фінансування інноваційної діяльності: джерела та перспективи розвитку/ Н.І. Ільук, І.О. Парфентьєва, П.О.Сунак // Збірник наукових праць Міжнародної науково-практичної конференції «Науковий парк та інноваційна інфраструктура університету як основа розвитку освіти та науки». - Луцьк : Східноєвроп. нац. ун-т ім. Лесі Українки, 2017. 216 с.

7. Інноваційна та науково-технічна сфера України : Inovations, Science and Technology of Ukraine : монографiя / Б.В. Гриньов, Д.В. Чеберкус, В.С. Шовкалюк та інші ; під загал. ред. Б.В. Гриньова. К. : НТУУ «КПІ» ВПІ ВПК «ПОЛІТЕХНІКА», 2014. 88 с.

8. Інновації в Україні: Європейський досвід та рекомендації для України. Том 3. Інновації в Україні : пропозиції до політичних заходів. - К. : Фенікс, 2017. 76 с. (проект СС «Вдосконалення стратегії, політики та регулювання інновацій в Україні».

9. Мельникова Ирина Стимулирование научно-инновационной деятельности: мировой опыт. Журнал международного права и международных отношений, 2018, № 3. Електронний ресурс. Режим доступу: http://evolutio.info/content/view/1728/232/.

10. Мельникова Ирина Стимулирование научно-инновационной деятельности: мировой опыт. // Журнал международного права и международных отношений, 2019, № 3. Електронний ресурс. Режим доступу: http://evolutio.info/content/view/1728/232/.

11. European Commission [Електронний ресурс] // Marie Curie Actions: country fact sheet: Ukraine. - Доступний 3 : http://ec.europa.eu/research/mariecurieactions/documents/fundedprojects/statistics/n on-eu/marie-curie-actions-country-fiche-ua_en.pdf.

12. France 2025 - Diagnostic stratégique: dix défis pour la France / Secrétariat d'État chargé de la prospective, del'évaluation des politiques publiques et du développement de l'économie numérique. 2009.

13. Freeman C. Prometheus unbound. In: The Economics of innovation. Al Elgar reference collection. Ed. By C. Freeman. London: Edward Elgar Publishing Company, 1990, pp. 487-500.

14. Goglio A. Policies to promote innovation in the Czech Republic / A. Goglio // OECD Economics Department Working Papers. №498. July 2016.

15. M. Henrekson and D. Johansson (2010) Gazelles as job creators: a survey and interpretation of the evidence, Small Business Economics (2015) 35: $227-244$. 
Економічні науки: збірник наукових праць Луиького національного технічного університету. Серія "Регіональна економіка". Випуск 17 (67). Редкол.: відп. ред. к.е.н., професор І.В. Кривов’язюк. Луцьк: ІВВ Луцького НТУ, 2020. 348 с.

16. HORIZON 2020 - Електронний ресурс. Режим доступу: http://ec.europa.eu/research/horizon2020/index en.cfm?pg=h2020.

\section{References}

1. Ekonomika I suspilstvo: nepiznani hrani vzaiemovplyvu (rozdumy nad prochytanym) / V. Heiets, A. Hrytsenko // Ekonomika Ukrainy . 2015. No. 3. P. 424.; Reitynh innovatsiinosti krain ES - Innovation Union Scoreboard 2013 [Elektronnyi resurs]. $\quad-\quad$ Rezhym doctupu: http://ec.europa.eu/enterprise/policies/innovation/files/ius-2013_en.pdf.].

2. Innovatsiinyi menedzhment: teoriia I praktyka $\mathrm{v}$ umovach transformatsii ekonomiky / V.I. Zaharchenko, N.M. Korsikova, M.M. Merkulov. Navch. posib. K. : Tsentr uchbovoii literatury, 2016. 448 p.

3. Zbirnyk naukovyh prats Mizhnarodnoii naukovo-praktychnoii konferentsii «Nuakovyi park ta innovatsiina infrastruktura universytetu iak osnova rozvytku osvity ta nauky». Lutsk: Shidnoievropeiskii Natsiiolanyi Universytet imeni Lesi Ukrainky, 2017. $216 \mathrm{~s}$.

4. Innovatsiina Ukraina 2020: natsionalna dopovid / za zah. red. V.M. Heitsia ta in. ; NAN Ukrainy. K., 2015. 336 p. : tabl., rys.

5. Innovatsinyi rozvytok / Za red. P.P. Mykytiuka. Ternopil: PP «Prynter Inform», 2015. $224 \mathrm{p}$.

6. Systema finansvannia innovatsiinoi diialnosti: dzherela ta perspektyvy rozvytku/ N. I. Ilchuk, I. O. Parfentieva, P. O. Sunak // Zbirnyk naukovych prats Mizhnarodnoii naukovo-praktychnoi konferentsii «Naukovyi park ta innovatsiina infrastruktura universytetu iak osnova rozvytku osvity ta nauky». Lutsk : Schidnoiavrop. nats. un-t im. Lesi Ukraiinky, 2017. 216 p.

7. Innovatsiina ta naukovo-technichna sfera Ukrainy: Inovations, Science and Technology of Ukraine : Monohrafiia / B.V. Hryniov, D.V. Cheberkus, V.S. Shovkaliuk ta inshi; pid zahal. red. B.V. Hryniova. K.: NTUU «KPI» VIP VPK «POLITECHNIKA», 2014. $88 \mathrm{p}$.

8. Innovatsii v Ukraini: Yevropeiskii dosvid ta rekomendatsii dlia Ukrainy. Tom 3. - Innovatsii v Ukraini: propozytsii do politychnuych zakhodiv. - K. : Feniks 2017. 76 p. (Proekt ES «Vdoskonalennia stratehii, polityky ta rehuliuvannia innovatsii v Ukraini».

9. Melnykova Irina Stimulirovaniye nauchno-innovatsionnoy deyatelnosti: mirovoy opyt // Zhurnal mezhdunarodnogo prava i mezhdunarodnykh otnosheniy, 2018, No. 3. Elektronny resurs. Rezhym dostupu: http://evolutio.info/content/view/1728/232/.

10. Melnykova Irina Stimulirovaniye nauchno-innovatsionnoy deyatelnosti: mirovoy opyt // Zhurnal mezhdunarodnogo prava i mezhdunarodnykh otnosheniy, 2019, No. $3 . \quad$ Elektronny resurs. Rezhym dostupu: http://evolutio.info/content/view/1728/232/.

11. European Commission [Електронний ресурс] // Marie Curie Actions: country fact sheet: Ukraine. - Dostupnyi z : http://ec.europa.eu/research/mariecurieactions/documents/fundedprojects/statistics/n on-eu/marie-curie-actions-country-fiche-ua en.pdf. 
Економічні науки: збірник наукових праць Луиького національного технічного університету. Серія "Регіональна економіка". Випуск 17 (67). Редкол.: відп. ред. к.е.н., професор І.В. Кривов’язюк. Луцьк: ІВВ Луцького НТУ, 2020. 348 с.

12. France 2025 - Diagnostic stratégique: dix défis pour la France / Secrétariat d'État chargé de la prospective, del'évaluation des politiques publiques et du développement de l'économie numérique. 2009.

13. Freeman C. Prometheus unbound. In: The Economics of innovation. Al Elgar reference collection. Ed. By C. Freeman. London: Edward Elgar Publishing Company, 1990, pp. 487-500.

14. Goglio A. Policies to promote innovation in the Czech Republic / OECD Economics Department Working Papers. №498. July 2016.

15. M. Henrekson and D. Johansson (2010) Gazelles as job creators: a survey and interpretation of the evidence, Small Business Economics (2015) 35: $227-244$.

16. HORIZON 2020 - Elektronnyi resurs. Rezhym dostupu: http://ec.europa.eu/research/horizon2020/index en.cfm?pg=h2020. 